\title{
Briterne stemte for studehandler
}

\section{Mads Qvortrup}

"En uge i politik er lang tid", sagde Labours leder og premierminister Harold Wilson i 1964. Hans diktum synes bekræftet af historien om valgkampen i 2010, der begyndte helt anderledes end den sluttede. Her er historien som den skred frem set fra ringside i den britiske hovedstad

Det begyndte godt for de Konservative. Labours 'Tax on Jobs' - det store oppositionspartis navn for den et procents stigning i den såkaldte $\mathrm{Na}$ tional Insurance Contributions (en særskat der går til sundheds- og socialområdet) - gav dem ammunition og medvind i medierne og blev yderligere styrket af at fremtrædende erhvervsfolk erklærede sig enige med oppositionsleder David Cameron.

Selv Alistair Darling, Labours finansminister, indrømmede at de Konservative havde haft 'en god uge'.

Men meningsmålingerne afspejlede ikke den positive medie- og presseomtale. De Konservative var faldet til 37 procent den 12. april, en uge efter valget var blevet udskrevet. $\mathrm{Og}$ det gav problemer. Det skyldes valg- systemet. Da Labour er stærkest i de tyndest befolkede områder, og da stemmeprocenten er højere i områder hvor de Konservative står stærkest, kræves der typisk 70.000 stemmer for at vinde et konservativt mandat. Modsat kræves der i gennemsnit kun 60.000 for at vælge et Labour-medlem af parlamentet. Og det er endnu værre for de Liberale Demokrater. I gennemsnit kræves der 120.000 stemmer for at vælge et liberalt medlem af Underhuset.

Denne tilsyneladende uretfærdighed betyder, at Labour kunne vinde et flertal af pladserne med kun 35 procent af stemmerne, mens de Konservative - alt andet lige - skulle vinde mindst 40 procent af stemmerne. Det havde de Konservative 
ligget til før jul. Men Browns håndtering af finanskrisen havde givet Labour luft, og en række fejltrin af de Konservative og uklarhed mht. deres økonomiske politik havde både svækket moralen og givet bagslag i meningsmålingerne. Ingen vidste hvor de Konservative stod; nogle gange var de for nedskæringer, så var de for hårdere straffe, og så for mere direkte demokrati. Med andre ord, de Konservative savnede en overordnet fortælling, et overordnet narrative som det hedder $\mathrm{i}$ jargonen.

Da valget blev udskrevet den 6 . april 2010 - lå Labour på 32 procent, mens de Liberale Demokrater (som ingen regnede med) var distanceret på 20 procent. De Konservative var $-\mathrm{i}$ bedste fald - på 38 procent.

Meget få forventede at dette ville ændre sig med offentliggørelsen af de tre partiers valgprogrammer eller manifestos, i valgkampens anden uge. Heri tog de ikke fejl.

\section{Partiprogrammerne}

Valgprogrammerne er et af de traditionelle indslag i britisk politik. Siden 1835, hvor den daværende konservative leder Sir Robert Peel offentliggjorde sit partis politik i sin valgkreds i Tamworth, har alle partier inden valget opstillet en liste over deres centrale valgløfter. Selvom det er de færreste vælgere der læser disse programmer, har de en forfat- ningsmæssig betydning. Ifølge den såkaldte Salisbury Konvention - der kan føres tilbage til slutningen af 1940'erne - accepterer The House of Lords (hvis medlemmer primært er udnævnt på livstid og ikke på valg) ikke at blokere politiske forslag som har vundet støtte i befolkningen ved et parlamentsvalg.

Det var traditionen tro regeringen der fremlagde deres program først. Med en forside der syntes at være hentet ud af den kinesiske kulturrevolution, fremlagde Labours program Fairness for All regeringspartiets gennemtravede, men ikke særligt spektakulære forslag som fx yderligere offentlige investeringer. $\mathrm{Og}-$ som madding for de Liberale Demokrater - var der løfter om folkeafstemninger om et nyt valgsystem. De foreslog det såkaldte AV-system. Dette system kendes fra Australien og giver vælgerne mulighed for at prioritere kandidaterne. Labour lovede også en folkeafstemning om et reformeret Overhus. Problemet med dette program var, at Labour havde lovet det hele før, nemlig i 1997, men at de havde glemt det hele, mens de havde absolut flertal. Mange opfattede derfor forslagene om en reform af det politiske system som opportunistisk valgflæsk.

Det konservative valgprogram fremlagt dagen efter på Battersea Power Station - det nedlagte kulkraftværk der er kendt fra coveret på Pink Floyd-albummet Animals - var langt fra at være traditionelt. Måske 
lidt lige som føromtalte Pink Floydalbum var Invitation to Join the Government lidt for alternativt og lidt for fortænkt og avanceret for den almindelige vælger.

Programmet var forfattet af partiets chefideolog, den tidligere filosofilektor i Cambridge Oliver Letwin, og indeholdt en række tankevækkende - men måske også nørdede forslag om, at borgerne skulle have ret til at kræve folkeafstemninger om lokalskatter, og andet i samme skuffe, heriblandt forslag om, at borgerne skulle have ret til at vælge deres egne politimestre.

Dette 'big society' - som det blev døbt af David Cameron - var nok et radikalt program, men ikke et der begejstrede almindelige vælgere, der sikkert undrede sig over, at det konservative parti ikke sagde mere om budgetunderskuddet, finanskrisen og indvandringspolitik.

Da de liberale demokrater fremlagde deres program Change that works for you, var fokus allerede flyttet fremad. Partiets forslag om at hæve den skattefrie bundgrænse fra knap 7000 Pund til 10.000 Pund og amnesti for illegale indvandrere druknede. Ingen interesserede sig for valgprogrammer. Alles blikke var rettede mod den meget omtalte tvdebat mellem partilederne fra de tre største nationale partier; David Cameron, Gordon Brown og Nick Clegg. Det var første gang at partilederne offentligt diskuterede på TV. Men Brown havde sagt ja til at delta- ge, og David Cameron havde accepteret - men havde insisteret på at Nick Clegg også skulle inviteres. Det havde Cameron gjort af frygt for Browns anerkendte evner som debattør. Dette var den første - og måske største fejl - i Camerons politiske karriere. Forklaringen kommer her.

\section{Partilederdebatterne}

Debatten tog seerne med storm. I en tid hvor TV mediet er erklæret dødt næsten dagligt, og i en tidsalder hvor alle taler om internettet, Facebook og Twitter, var det i sig selv tankevækkende, at over 30 procent af seerne så i hvert fald dele af debatten. Resultatet var en overraskelse for alle. Nick Clegg - manden som dagen forinden havde været en politisk joke - vandt. Meningsmålinger foretaget under og efter udsendelsen viste, at 61 procent af seerne opfattede den liberale leder som den klare vinder. Kun 22 procent kårede David Cameron til vinder, og sølle 17 procent mente, at Gordon Brown var gået af med sejren.

Fokus-grupper foretaget af den amerikanske spindoktor Frank Lunz for BBC Programmet The Today Programme viste, at de fleste opfattede Clegg som 'et frisk pust', mens David Cameron blev opfattet som 'utroværdig'. Gordon Brown blev beskrevet med ord som 'gammel' og 'surmulende'.

Clegg havde vundet første runde 
på at tale direkte til kameraet, på at tiltale tilhørerne med deres fornavne og på at virke oprigtig. Det image holdt han valgkampen igennem. Selvom de næste to debatter ikke var så store succeser som den første, var der ingen tvivl om, at den liberale leder var den mest fotogene og karismatiske af de tre.

Cleggs succes torpederede den konservative strategi. Godt hjulpet af penge fra mangemillionæren Lord Michael Ashcroft havde de Konservative ført en frontal kampagne mod Gordon Brown. Men partiet skulle også vinde stemmer - og valgkredse - i det liberalt dominerede Sydøstengland for at vinde de 117 pladser, der krævedes for at få absolut flertal i det 650 pladser store Underhus (House of Commons). For at gøre dette måtte de slå Clegg. Men det viste sig svært.

Det naturlige ville have været, at angribe Clegg - den ældste søn af en hovedrig halv-russisk bankmand - som et overklasseløg, der havde gået på en af landets dyreste privatskoler, nemlig Westminster, hvor det årlige undervisningsgebyr er på 28.000 pund (over 200.000 kroner!). Men denne strategi var udelukket, da de Konservative ikke ønskede at skabe unødig opmærksomhed om at David Cameron (og flere af hans skyggeministre) havde gået på Eton (en endnu mere eksklusiv privatskole).

Den anden oplagte mulighed, at angribe Clegg for hans pro-euro- pæiske (læs EU-begejstrede) synspunkter, var ligeledes udelukket, da Clegg havde været kabinetchef for den konservative (sic!) EU-kommissær Sir Leon Brittan.

Alt imens dette skete, var de Konservatives opbakning i meningsmålingerne faldet til 32 , mens de Liberale Demokrater med 29 procent havde overhalet Labour på 28.

"Events. Events, dear boy" - sagde forhenværende premierminister Harold Macmillan, da han i slutningen af 1950'erne blev spurgt om, hvad der styrede den daglige politik. Selv en valgkamp ligger under for naturens luner. Den tredje uge af valgkampen var ikke så meget præget af politik, som den var præget af den islandske askesky, der lagde sig som en gråhvid dyne over det britiske ørige, og som førte til flyveforbud for de tre partiledere og millionvis af flypassagerer.

Men da vulkanasken forsvandt, var jagtsæsonen på Nick Clegg i gang. Den britiske presse er mere partisk end den danske. Dagblade som The Sun, The Daily Mail - og blandt de mindre sensationsprægede The Daily Telegraph indledte en klapjagt på den liberale leder. The Sun stillede spørgsmålstegn ved, om Clegg var britisk (hans moder er hollænder og hans farmor var russer), og The Daily Mail antydede helt uden skyggen af bevis - at Clegg havde nazistiske sympatier ('Clegg in Nazi Slur on Britain' lød overskriften den 22. april). 
Men lige meget hjalp det. Clegg vandt den anden tv debat om end ikke så klart som den første, og i meningsmålingerne var de Liberale Demokrater stadig på 30 procent - lige bag de Konservative på 33 .

De Konservative prøvede - mere eller mindre desperat - at skabe frygt om et hung parliament - den engelske betegnelse for det man i Danmark engang kaldte 'et grumset flertal'. Den tidligere konservative finansminister Kenneth Clarke (der burde vide bedre) sagde, at et parlament hvori ingen af de store partier havde flertal alene, ville føre til, at Den Internationale Valutafond ville gribe ind, og at Storbritannien ville ende som Grækenland. Pudsigt nok glemte Clarke at sige, at den græske regering har flertal alene. Men den slags politologiske detaljer spiller ikke den store rolle i praktisk politik.

Men den megen fokus på 'grumsede flertal' overbeviste ikke vælgerne. Parlamentsvalg vindes ikke på teoretiske overvejelser om valgsystemet, men på konkret politik. Dette valg var ikke anderledes. 83 procent opfattede finanskrisen som et vigtigt problem. Lige efter fulgte spørgsmål som sundhedsvæsenet (63 procent), indvandring (61 procent) og uddannelse (52). Kriminalitet - eller rettere frygten herfor - havde været et hovedemne i valgene i 1997, 2001 og 2005. Det var ikke længere tilfældet. Kriminaliteten var faldet med næsten 50 procent som et resultat af Labours hårde retspolitik. Men den lave kriminalitet blev taget for givet - og Labour kunne ikke høste de politiske laurbær. Sådan går det ofte i politik. Vejen ud af kridthuset kan være utrolig kort. Den megen omtalte politikerlede - og vreden over at mange politikere havde fået godskrevet lidt for mange og lidt for fantasifulde udgifter, spillede ikke en større rolle for vælgerne.

De Konservatives fokus på de Liberale Demokrater betød, at Labour kunne fokusere på deres budskab om genopretning. Men Labours valgkamp var ikke så velsmurt som i de hedengangne New Labourdage. Og så havde partiet ikke heldet på deres side. Den dag Labour lancerede deres valgplakater, skete der et trafikuheld 20 meter fra der, hvor Gordon Brown og hans mest betroede medarbejdere talte. Men det var ikke det mest bemærkelsesværdige der skete den 28. april.

\section{Mrs. Duffy}

"I enhver valgkamp er der et selvmål. Og dette var det", sagde Philip Gould, Labours nu halvpensionerede pollster. Det som den hærdede partiveteran talte om, var Mrs. Gillian Duffy. En pensioneret fabriksarbejder som Gordon Brown talte med i Rochdale i Nordengland. Samtalen var venlig nok. Og alt tyder på, at ingen ville have hørt om Fru Duffy, dersom Brown ikke havde glemt at tage sin mikrofon af. Men uheldet var ude. Vel inde i sin mini- 
sterbil erklærede Brown, at Mrs. Duffy var en typisk 'snæversynet kælling'. Det blev transmitteret til de små hjem. Brown forsøgte at udbedre skaden ved at tage tilbage til Fru Duffy for at undskylde og derefter erklære foran alverdens tv-kameraer, at han - den ældste søn af en skotsk landsbypræst - var en 'angrende synder'.

Dette hjalp ham ikke i den sidste debat med Clegg og Cameron dagen efter, men modsat sårede det ham heller ikke dødeligt - som nogle havde forventet.

Brown gjorde faktisk en god figur i de sidste dage af valgkampen. Labour halede endog ind på de Liberale Demokrater. Og to dage inden valget lå de to partier side om side $\mathrm{i}$ meningsmålingerne. De Konservative havde genvundet lidt af den tabte kampgejst, men var med 35 procent stadig under de magiske 40 procent.

De sidste dage af valgkampen var som støvsuget for politisk indhold. Gordon Brown holdt en brandtale i Central Methodist Hall, hvori han med en retorik der ville have passet bedre i det romerske Senat end i det 21. århundredes Storbritannien talte med en patos der ville have været Julius Cæsar værdig: "Det er blevet sagt at når Cicero talte, lyttede de og sagde til hinanden. God tale. Det er blevet sagt om Demosthenes, at når han talte, så sagde de til hinanden, lad os marchere. Jeg siger marcher! Lad os gå fremad. Fremad mod social retfærdighed".
Muligvis god retorik - men den klassisk dannede Brown glemte at sige, at Demosthenes (den græske retoriker fra det 4 . århundrede før kristus som han henviste til) ikke havde succes med sit forehavende. Hans opgør med makedonerne slog fejl, og han måtte gå i landflygtighed, hvor han begik selvmord i vanære.

\section{Konservativ sejr, men ikke flertal}

Den første valgprognose torsdag den 6. maj torpederede alle forudsigelserne og fik analyseinstitutterne til at ømme sig over, at de (igen) havde regnet forkert.

De Konservative havde vundet 37 procent, Labour 29 og de Liberale kun 23. Men på grund af valgsystemet havde de Konservative ikke flertal. De 37 procent rakte kun til 307 pladser i Parlamentet. Og selvom de Liberale Demokrater fik en fremgang på to procent, fik de færre pladser end i det afgåede parlament, kun 57 mod tidligere 60 . Labour fik 258 - et tab på over 100 mandater.

Dagen derpå erklærede Nick Clegg - helt i overensstemmelse med sine udtalelser inden valget, at det parti der fik flest stemmer, havde en 'moralsk ret' til at danne regering.

Men Brown tog ikke konsekvensen og trådte ikke tilbage. Han konstaterede - om end med værdighed - at han ville lade embedsmænd ar- 
bejde med De Liberale og De Konservative i de to partiers forsøg på at finde et regeringsgrundlag. Men han gjorde samtidigt klart at Labour - dersom forhandlingerne mellem de Konservative og de Liberale Demokrater brød sammen - ville forhandle med Cleggs parti.

Brown erklærede samtidigt, at han ville tilbyde en folkeafstemning om et nyt valgsystem; noget som Liberal-Demokraterne - eller rettere deres forløber - havde kæmpet for siden 1931.

Brown kom dermed Cameron i forkøbet. Den konservative leder så ud til at have tabt tid, da han tyve minutter senere - klokken 15.15 om fredagen - sagde, at han ville indgå forhandlinger med Clegg. Men han overraskede alle ved at sige at han ikke ønskede en 'confidence and supply' ordning - altså en aftale hvor de Liberale Demokrater skulle være et fast støtteparti. Han ønskede en koalitionsregering. I sin korte tale erklærede han samtidigt, at han ikke ville gå på kompromis med spørgsmålet om yderligere EU-integration, yderligere indvandring, samt at hans parti ikke ville diskutere den del af forsvarspolitikken der omhandlede Storbritanniens Trident atomvåben. Også i spørgsmålet om et nyt valgsystem var han nølende, og ville 'højst' etablere et udvalg der kunne diskutere spørgsmålet. Noget som Tony Blair havde gjort - hvorefter han ignorerede udvalgets konklusioner! De Liberale kunne med en vis ret frygte en gentagelse.

Trods det noget beskedne udgangspunkt mødtes de to partier til forhandlinger. I koreograferede udtalelser sagde begge delegationer at drøftelserne var 'positive'. Et privat møde mellem David Cameron og Nick Clegg om lørdagen blev af begge partiers spin doktorer omtalt som 'venskabeligt'. Modsat blev et kort møde mellem Brown og Clegg betegnet som 'køligt og ubehageligt'.

Mandag morgen tegnede alt til en koalitionsregering - også selvom de Liberale Demokrater tilsyneladende ikke fik opfyldt deres mest eftertragtede ønsker. Men så begyndte situationen at ændre sig. En forligsskitse blev forelagt parlamentsgruppen mandag formiddag. Men gruppen sendte skitsen tilbage og udbad sig forklaringer om enkelte punkter. Der var krisestemning i det konservative parti.

Premierministeren kom igen på banen. Brown - som avisen The Sun havde døbt 'slumstormeren i Downing Street' - tilbød, at han ville indgå i parallelle forhandlinger med de Liberale Demokrater. Han var sig bevist, at de to partier tilsammen manglede 9 pladser i at have flertal, men han regnede med, at både nationalister i Skotland (de seks mandater fra The Scottish National Party), Wales (Plaid Cymrus 3 medlemmer) og det nyvalgte, enlige medlem af De Grønne, Caroline Lukas, ville støtte en mindretalsregering. Det virkede ikke usandsynligt rent 
politisk og indholdsmæssigt, da alle disse partier er til venstre for midten. Men politik handler ikke blot om holdninger, det handler også om stemninger, psykologi og om hvad der 'føles' rigtigt.

Cameron fremlagde sit 'sidste tilbud'; et løfte om en folkeafstemning om valgsystemet og en reform af Overhuset. Det gjorde udslaget, de Liberale Demokraters møde med Labours forhandlingsdelegation varede kun en time. At mange fremtrædende Labour-politikere - folk som Jack Straw, John Reid og David Blunkett - i medierne opfordrede Brown til at gå af, gjorde ikke situationen lettere for Ed Balls, Labours forhandlingsleder.

\section{Registreret partnerskab}

Sidst på eftermiddagen om tirsdagen trådte Brown frem foran Downing Street for sidste gang. En time senere - klokken 19.20 - kørte en Jaguar ud af Buckingham Palace. I den sad David William Cameron, den yngste premierminister siden Lord Liverpool i 1812.

Dagen efter blev Nick Clegg udnævnt til vicepremierminister. Han er den første liberale i en regering siden 1945.

De Konservative tog hovedparten af pladserne, med William Hague som udenrigsminister og George
Osborne som finansminister. Men den liberale Vince Cable fik den fremtrædende post som erhvervsminister, og de liberale fik lovning på mærkesager på det økonomiske område.

Mange - især i medierne - var perplekse over den nye situation. Nogle muntrede sig over den næsten nyforelskede stemning på Cleggs og Camerons første pressemøde. The Sun erklærede drilsk at de to mænd havde indgået et registreret partnerskab - i platonisk forstand, begribeligvis!

Andre mere seriøse aviser såede tvivl om det rimelige $i$ at to partier, der gik til valg på et løfte om mere åbenhed, havde indgået en aftale bag lukkede døre. Svaret til disse kritikere blev formuleret af den ellers højreorienterede konservative politiker Ed Leigh (paradoksalt en af dem der var mest skeptisk over for det nye borgerlige ægteskab). Som han sagde: "Der er ikke noget i vejen med studehandler bag lukkede døre. Sådan har den britiske forfatning - Gud velsigne den - altid fungeret!"

\section{Mads Qvortrup er forskningschef på Cranfield University og the Defence Academy of the United Kingdom. Han er også TV2-News' korrespondent i Storbrit- annien.}

